Tomasz Leś

Uniwersytet Jagielloński

\title{
Idee Szkoły Lwowsko-Warszawskiej w pedagogice na przykładzie poglądów Kazimierza Sośnickiego
}

\author{
Abstract \\ The ideas of the Polish Lvow-Warsaw School in educational research by \\ the example of the Kazimierz Sośnicki's conception
}

This article concerns the selected theoretical research by Kazimierz Sośnicki in the field of Educational Theory in the context of his relations to the Polish Philosophical LvowWarsaw School. Author argues on the thesis that his way of doing research is closely related to the way philosophical problems are analyzed by the school. Firstly, Sośnicki worked on improving culture of logic and precise thinking among students; secondly, his way of doing research was based on the postulates of the school - precise, systematic, non-normative analysis of concepts and conceptions from different areas of science and philosophy; thirdly, he proposed a comprehensive program which provided grounds for application of philosophical analysis in educational research.

Key words: Kazimierz Sośnicki, The Lvow-Warsaw School, philosophy of education, educational philosophy

Słowa kluczowe: Kazimierz Sośnicki, Szkoła Lwowsko-Warszawska, filozofia edukacji, pedagogika filozoficzna

\section{Wstęp}

Kazimierz Sośnicki w dyskursie pedagogicznym znany jest przede wszystkich z dokonań na gruncie dydaktyki, jego podręczniki z tego zakresu uchodzą za klasyczne. Jednak całość idei, które proponuje, obejmuje również zagadnienia dotyczące statusu pedagogiki jako nauki, sposobów jej uprawiania czy konstruowania systemów pedagogicznych. Są to zatem w głównej mierze zagad- 
nienia filozoficznych podstaw pedagogiki. Dodatkowo, sama próba analizy tych problemów przybrała u niego specyficzną formę, której podstawowe zasady sformułowane zostały w ramach tak zwanej Szkoły Lwowsko-Warszawskiej.

Celem artykułu jest prezentacja i rekonstrukcja wybranych poglądów Kazimierza Sośnickiego na pedagogikę w kontekście podstawowych idei Szkoły Lwowsko-Warszawskiej. Najpierw krótko zaprezentowana zostanie sylwetka omawianego filozofa i pedagoga, jego związki z przedstawicielami Szkoły Lwowsko-Warszawskiej i podstawowe jej założenia. W dalszej dokonana zostanie rekonstrukcja wybranych twierdzeń dotyczących pedagogiki oraz Sośnickiego próba przeniesienia na grunt pedagogiki idei szkoły.

Pedagogika jest specyficzną dziedziną wiedzy; wymaga w wysokim stopniu znajomości innych dziedzin. W jej przypadku ważną, pomocniczą rolę przyznaje się przede wszystkim psychologii, socjologii i filozofii. Pogłębiona ich znajomość stanowi warunek konieczny dla stworzenia oryginalnej i trwałej wiedzy w omawianej dyscyplinie. Wpisując się w transdyscyplinarny nurt uprawiania pedagogiki, Kazimierz Sośnicki spełnia powyższy warunek. Jednocześnie stanowi on przykład badacza, który rzetelnością naukową i stylem uprawiania pedagogiki nie tylko już na trwałe wpisał się $\mathrm{w}$ dobre tradycje polskiej pedagogiki, lecz również mimo upływu kilkudziesięciu lat od jego śmierci pozostawił po sobie wiele aktualnych i wciąż jeszcze czekających na podjęcie idei.

\section{Sośnicki i Szkoła Lwowsko-Warszawska}

Kazimierz Sośnicki (ur. 1883 we Lwowie - zm. 1976 w Gdańsku) należał do tych badaczy, których trudno jednoznacznie zaklasyfikować; był filozofem, pedagogiem (w tym dydaktykiem), studiował też matematykę i fizykę, interesował się psychologią. Racje mają pedagodzy, którzy uznają go za przedstawiciela swojej dyscypliny, ale biorąc pod uwagę wczesny okres pracy badawczej, jako że zajmował się logiką i metodologią nauk, mógłby być z powodzeniem potraktowany również jako filozof. $Z$ pewnością w sposób twórczy łączył obie dziedziny wiedzy, a jak zostało wspomniane, jego idee stanowią ważny element $\mathrm{w}$ filozoficznym dyskursie nad pedagogiką (i wychowaniem) ${ }^{1}$.

Sośnicki kształcił się pod kierunkiem Kazimierza Twardowskiego, twórcy Szkoły Lwowsko-Warszawskiej i to właśnie idee tej szkoły wpłynęły zasadniczo

1 Szczegółowe opracowania pedagogiki K. Sośnickiego zob. m.in. Nalaskowski (1997); Gajdamowicz (1991). 
na jego sposób analizy problemów pedagogiki i wychowania ${ }^{2}$. Mimo znacznych dokonań szkoły (nie tylko na gruncie filozofii polskiej) i wagi podnoszonych problemów, istotnych również dla pedagogów, jej idee nie zostały w pedagogice w wystarczającym stopniu podjęte. Sośnicki stanowi tu zatem wyjątek.

Twórcą Szkoły Lwowsko-Warszawskiej był wspomniany K. Twardowski, który część idei filozoficznych F. Brentano chciał przenieść na grunt polski³. Ostatecznie, $\mathrm{w}$ trakcie aktywności przedstawicieli szkoły (pierwsza połowa $\mathrm{XX}$ wieku), część idei Brentano zostało poszerzonych, a nowo podjęte inspiracje i badania nadały szkole oryginalny charakter. Było to zresztą zgodne z zamierzeniem jej twórcy, który chciał stworzyć niezależną filozofię polską. Twardowski z czasem wykształcił i zorganizował wokół swojej osoby nie tylko filozofów, ale i (choć w zdecydowanie mniejszym stopniu) między innymi psychologów (W. Witwicki), filologów (J. Kuryłowicz), matematyków (H. Steinhaus) i pedagogów (K. Sośnicki, B. Nawroczyński), z których część idee szkoły starała się przenosić na inne dziedziny wiedzy. Trudno o jej jednoznaczną charakterystykę, zakres problemowy, jakim się zajmowano, był stosunkowo szeroki. Można tu mówić właściwie o większości dziedzin filozofii: logice (logika trójwartościowa J. Łukasiewicza, mereologia S. Leśniewskiego), metodologii (klasyfikacje rozumowań Łukasiewicza, Czeżowskiego i Ajdukiewicza), epistemologii (semantyczna teoria prawdy A. Tarskiego), ontologii (reizm T. Kotarbińskiego), historii filozofii (Łukasiewicza nowa interpretacja związków logiki stoików z logiką Arystotelesa, historia estetyki W. Tatarkiewicza), etyki (etyka niezależna T. Kotarbińskiego, etyka empiryczna T. Czeżowskiego) (Woleński, 2005). Wspólnym elementem był z pewnością sposób analizy problemów filozoficznych. W skrócie sprowadzał się on między innymi do następujących zasad (Woleński, 2005):

(1) w formułowaniu problemów i stawianiu tez należy dążyć do ich jak największej jasności, precyzji i uzasadnienia;

(2) należy unikać zagadnień spekulatywnych (to jest „metafizycyzmu”), a każdą istotną kwestię badać szczegółowo i oddzielnie;

(3) filozofia powinna być neutralna światopoglądowo;

(4) filozofia, mimo że z analizy nie wyklucza, to jednak nie dąży do budowania wielkich systemów filozoficznych (minimalizm metafizyczny);

(5) w związku z odróżnieniem czynności od wytworów psychicznych filozofia, inaczej niż psychologia, zajmuje się wytworami czynności psychicznych (między innymi językiem teorii naukowych);

2 Innym pedagogiem, kształcącym się pod kierunkiem K. Twardowskiego był Bogdan Nawroczyński.

3 Szczegółowe opracowania na temat Szkoły Lwowsko-Warszawskiej zob. m.in. Woleński (1985, 1997); Moroz (2013). 
(6) omawiana nauka powinna być antyirracjonalna, to jest jej twierdzenia powinny być intersubiektywnie komunikowalne i sprawdzalne;

(7) w badaniach filozoficznych nie należy rezygnować $\mathrm{z}$ dokonań innych dziedzin wiedzy, głównie nauk szczegółowych;

(8) warunkiem żywotności filozofii (i każdej nauki) jest jej wewnętrzna dynamika (niewykluczająca sporów), z tego powodu filozofia powinna być autokrytyczna.

Jan Woleński między innymi takimi słowami charakteryzuje Szkołę Lwowsko-Warszawską:

Był więc program metafilozoficzny szkoły lwowsko-warszawskiej programem filozofii analitycznej, krytycznej, trzeźwej, wolnej od dogmatyzmu, jasno wyrażanej i stroniącej od spekulacji. Była to filozofia minimalistyczna, gdyż kładła nacisk na problemy, a nie na systemy. Nie była natomiast minimalistyczna w sensie zakazywania podejmowania jakichkolwiek problemów - każdy problem podniesiony w przeszłości nadawał się do rozważania, o ile był należycie sformułowany. Nie zakazywała też syntez i systemów, natomiast postulowała systemy i syntezy jako produkty wtórne, a nie podstawy wyjściowe (Woleński, 1984, s. 206).

Wskazane powyżej zasady wiązały się z próbą unaukowienia filozofii ze względu na metodę, miała zatem spełniać wymóg między innymi jasności, precyzji, uzasadnienia, neutralności światopoglądowej, a biorąc pod uwagę fakt, że podstawowym przedmiotem badań był język (teorii, systemów itd.), Szkoła Lwowsko-Warszawska wpisuje się w analityczny nurt uprawiania omawianej dziedziny wiedzy ${ }^{4}$.

\section{Sośnickiego program analizy filozoficznej w pedagogice}

Wyżej sformułowane zasady stanowią podstawę pracy badawczej K. Sośnickiego; był jednym $\mathrm{z}$ niewielu (jeśli nie jedynym) reprezentantem nurtu analitycznego w pedagogice 5 . Powody takiego stanu rzeczy (to jest braku analizy filozoficznej w pedagogice) z pewnością nie mają uzasadnienia merytorycznego; badania tego rodzaju są nie tylko możliwe, ale i z pewnych względów konieczne na gruncie omawianej tu dziedziny. Jest to możliwe ze względu na ścisły związek filozofii z pedagogiką; pomijając argumenty genetyczne sprowadzające się do twierdzenia, że pedagogika wyodrębniła się z filozofii, należy w tym miejscu wskazać na dwa następujące fakty. Po pierwsze, sama analiza pojęcia wychowania, to jest podstawowego pojęcia pedagogiki, ujawnia, że wychowanie jako działanie jest zorganizowane na cel (cele pośrednie i naj-

4 Szczegółowo na temat filozofii analitycznej zob. m.in. Glock (2008).

5 Część prac S. Wołoszyna można zaliczyć do omawianego nurtu. Zob. Wołoszyn $(1961,1997)$. 
wyższy cel działania wychowawczego) i jako takie dotyczy pożądanych stanów rzeczy wyrażanych w teleologicznych normach wychowawczych. Normy te $\mathrm{z}$ kolei uzasadniane są $\mathrm{w}$ ramach określonych systemów filozoficznych (stąd zasada: zmiana filozofii pociąga za sobą zmianę pedagogii). Filozofia stanowi zatem kontekst uprawiania pedagogiki. Po drugie, pedagogika rozumiana jako system pedagogiczny oprócz tego, że opiera się na założeniach normatywnych wywodzących się z filozofii (głównie etyki), to same systemy, traktowane jako system zdań, wykazują analogiczną strukturę do systemów filozoficznych (w szczególności etyczno-normatywnych), to jest od zdań-pryncypiów filozoficzno-etycznych do wskazówek odnoszących się do działania. Pedagogika zatem dziedziczy niektóre problemy filozofii (szczególnie związane z normatywnością), ale i jej struktura przyjmuje podobną formę do systemów filozoficznych. Filozof analityczny ma na jej (pedagogiki) gruncie szerokie pole badawcze, od samych związków filozofii, etyki z pedagogiką, poprzez analizę problemów wspólnych tym dyscyplinom, kończąc na badaniu struktury logicznej systemów pedagogicznych. Jak zostało wspomniane, analizy takie są również, zakładając określone potrzeby związane $\mathrm{z}$ trwaniem i rozwojem nauki, konieczne. Odwołując się do zasady wyrażonej w (8), krytyka i autokrytyka stanowią podstawę żywotności i dynamiki każdej nauki. W pedagogice jest to tym bardziej istotne, że nierzadko zarzuca się jej jałowość podejmowanych problemów czy zbytnie zaangażowanie ideologiczne. Krytyka innych nurtów pedagogicznych, ale szczególnie autokrytyka, może przyczynić się do, przynajmniej częściowego, osłabienia tych zarzutów ${ }^{6}$.

Badania Sośnickiego, w których podejmuje on zagadnienia związane z pedagogiką, stanowią ścisłe zastosowanie postulatów Szkoły Lwowsko-Warszawskiej. Dotyczy to zarówno tych, w ramach których zajmował się dydaktyką (Sośnicki, 1948) (stąd nazwa: dydaktyka analityczna), ale i tych dotyczących zagadnień filozoficzno-pedagogicznych (Sośnicki, 1946, 1964, 1967). Odnajdziemy tam zatem szczegółowe analizy takich pojęć, jak kształcenie, nauczanie, plan nauczania, cele wychowania. Na kilkuset stronach analizie poddaje wszystkie podstawowe pojęcia związane $\mathrm{z}$ teleologią wychowania, wskazując również na relacje między tymi pojęciami (wychowanie, cel wychowania, podmiot wychowania, przedmiot wychowania, sytuacja wychowawcza, normy wychowawcze, dyspozycje itd.) (Sośnicki, 1964). W badaniach metapedagogicznych z kolei odnaleźć można próby definicji takich pojęć, jak między innymi

6 Uzasadnienie mogą tu stanowić następujące słowa S. Wołoszyna (1997, s. 11): „Refleksja naukowa nie może zostać «rozmieniona» na wielość niespójnych, niekoherentnych, a nawet wzajemnie zwalczających się ideologii. Musi poszukiwać kategorii ogólnych, a te przede wszystkim - moim zdaniem - poddawać analizie formalnej. Pedagogika cierpi na niedostatek takich analiz, a zajmować się nimi powinna nade wszystko pedagogika ogólna”. 
pedagogika, system pedagogiczny, przedmiot pedagogiki (Sośnicki, 1998). Jest to zatem, w pierwszym przypadku, rekonstrukcja aparatury pojęciowej dydaktyki, w drugim, teleologii wychowania, w trzecim, pedagogiki jako nauki.

Jednym z ważniejszych dokonań Sośnickiego w ramach badań metapedagogicznych było wskazanie przez niego struktury logicznej (normatywnego) systemu pedagogicznego. Wykazał, że opiera się on na schemacie, w którym na podstawie założeń filozoficznych i dołączanych do nich praw formułowanych przez między innymi psychologię i socjologię, wyprowadza się konkretne zalecenia wychowawcze. Zwrócił też uwagę na problem równoważności tych systemów:

Systemy te wymagają dla siebie rangi „naukowości”, gdyż opierają się one nie tylko o teorie i pomysły filozoficzne, ale też o naukowe prawa wielu nauk pomocniczych, a więc o prawa psychologii, socjologii, epistemologii, logiki, nauk historyczno-kulturalnych itp. Ogólny jednak kierunek dociekań pedagogicznych i ich podstawowe założenia są zaczerpnięte z pewnego prądu filozoficznego (...). Ponieważ oparcie systemu pedagogicznego o poszczególne nauki i o filozofię może być jeszcze bardzo rozmaite i może korzystać z różnych stron nauk pomocniczych i w różnej mierze je uwzględniać, więc przez ten „naukowy” charakter nie jest jeszcze zagwarantowana wyłączność jednego systemu, a wykluczenie prawa do naukowości w stosunku do innych. Dlatego pedagogika filozoficzna nie wytwarza jakiegoś jednego systemu pedagogicznego, ale dopuszcza możliwość wielu postaci różnych systemów (Sośnicki, 1998, s. 98).

Istotnym elementem jego badawczego dorobku jest analiza problemu podnoszonego również współcześnie, mianowicie statusu naukowego pedagogiki. Według niego może ona być identyfikowana w każdym z elementów następującego podziału: (1) nauka przyrodnicza, (2) nauka humanistyczna, (3) technika (filozofia praktyczna), (4) sztuka (Sośnicki, 1967, s. 13-19). Jednocześnie Sośnicki dostrzega wagę problemu ewentualnego braku autonomiczności pedagogiki (na przykład przez redukcję do psychologii i socjologii). Pisze o tym w następujący sposób:

(...) nie brak też poglądów, że pedagogika nie jest nauką. Twierdzenie takie ma dwa główne uzasadnienia. Jedno z nich odmawia jej charakteru autonomii naukowej. Nie ma ona rzekomo odrębnego przedmiotu badania, gdyż cele wychowania i środki pochodzą z innych nauk, a więc od socjologii, biologii, psychologii, etyki itd. Tak więc na cały proces wychowania składają się treści innych nauk, a pedagogika jest tylko kompleksem rezultatów badań tych nauk zastosowanym do wychowania (Sośnicki, 1967, s. 17).

\section{I dalej:}

W ramach innego poglądu odmawiającego pedagogice naukowości - [przyp. T.L.]. Nie można (...) postawić żadnych prawidłowości w procesie wychowania, gdyż wychowanie jest odmianą działalności artystycznej. Jako dzieło sztuki jest rezultatem artystycznej koncepcji 
i artystycznego wykonania, tak też sztuką jest kształtowanie psychiki człowieka (Sośnicki, 1967, s. 17).

Ostatecznie wydaje się, że skłania się ku traktowaniu omawianej dziedziny wiedzy jako autonomicznej (uzasadniając to faktem posiadania wyróżnionego przedmiotu i metod badawczych), jednocześnie posiadającej cechy każdej z wymienionych wyżej dziedzin, to jest (1-4) (w sposób szczególny podkreśla jej związki z filozofią).

Sośnicki prowadził badania analityczne nie tylko samych pojęć, lecz także systemów i koncepcji pedagogicznych. Badania takie, w ogólności charakteryzowane jako opisowo-porównawcze, sprowadzały się do analizy logicznej struktury tych systemów i koncepcji, ich założeń, w tym podstaw (założeń) filozoficznych, relacji między tymi systemami i ich krytyki. Były to zatem badania zarazem szerokie i pogłębione, zdające sprawę z całości teoretycznej charakterystyki podejmowanego przedmiotu. Odnajdziemy tu też próby rekonstrukcji poglądów na wychowanie u filozofów, wśród których pedagodzy rzadko poszukują wartościowych, z perspektywy ich dziedziny, twierdzeń, między innymi poglądy B. Russella i A.N. Whiteheada, J. Deweya czy egzystencjalistów (Sośnicki, 1967). Wykorzystanie źródeł pozapedagogicznych nie sprowadza się jednak wyłącznie do filozofii (choć występuje ono najczęściej). W swoich analizach Sośnicki wykorzystuje wyniki badań psychologicznych, socjologicznych, ale i z zakresu genetyki. W tym ostatnim przypadku dokonuje próby zmierzenia się $\mathrm{z}$ również współcześnie obecnym $\mathrm{w}$ niektórych teoriach korzystających z ustaleń biologii ewolucyjnej nurtem głoszącym nieistotny wpływ oddziaływania wychowawczego (współcześnie między innymi Mark Hauser, David Buss). Wskazując na falsyfikujące te teorie badania z zakresu genetyki, stara się wykazać, że pogląd taki opiera się na wybiórczym traktowaniu teorii naukowych (Sośnicki, 1964). Podobnie jak inni przedstawiciele Szkoły Lwowsko-Warszawskiej kładł duży nacisk na rozwijanie kultury logicznej; oprócz tekstów naukowych publikował również prace o charakterze poradników, mające służyć podnoszeniu umiejętności pracy naukowej: Zarys logiki dla klas wyższych szkół średnich ze szczególnem uwzględnieniem seminarjów nauczycielskich (1929), Jak studiować dzieło pedagogiczne (1966), Poradnik dydaktyczny (1971).

Próba zastosowania idei Szkoły Lwowsko-Warszawskiej w pedagogice przybrała u omawianego filozofa-pedagoga wymiar programowy; w sposób systematyczny wyłożył zbiór zasad (które - jak widać na podstawie powyższych uwag - sam stosował) pokrywających się z przyjętymi w szkole, ale odnoszącymi do pedagogiki - program tak zwanej pedagogiki filozoficznej. Wskazał w nim na potrzebę precyzyjnej, nienormatywnej analizy pojęć i sy- 
stemów pedagogicznych, mającej na celu ich rekonstrukcję, opis, porównanie, szczególnie ze względu na założenia filozoficzne:

Stanęłaby ona [pedagogika filozoficzna - przyp. T.L.] jak gdyby ponad poszczególnymi systemami, a stąd też ponad kierunkami filozofii, a z filozofii zatrzymałaby jedynie raczej metodę, ogarniającą całość zasad, pojęć, prądów i kierunków pedagogicznych. Badania te z natury rzeczy muszą być jedynie porównawcze i opisowe, a nie normatywne i nie prowadzą do ustalenia żadnego systemu. Dają one natomiast zasadniczy przegląd spraw pedagogicznych w sposób porównawczy i otwierający szerokie horyzonty na poszczególne pojęcia i zasady pedagogiczne (Sośnicki, 1998, s. 100).

Realizacja wspomnianego programu zakłada przyjęcie następujących zasad:

(1) pedagogika filozoficzna zbiera, porównuje i klasyfikuje rozpatrywane i rozwiązywane zagadnienia poszczególnych systemów pedagogicznych;

(2) zbiera, porównuje i klasyfikuje metody i wyniki rozwiązywania problemów w poszczególnych systemach;

(3) dokonuje analizy semantycznej pojęć pedagogicznych, jednocześnie porównując je i badając relacje między nimi;

(4) dokonuje analizy charakterystycznych własności systemów pedagogicznych, porównuje systemy ze względu na te własności, bada ich genezę;

(5) dokonuje analizystrukturylogicznej systemów pedagogicznych, wszczególności rekonstruując ich fundamenty filozoficzne i światopoglądowe.

Był to zdecydowanie nowatorski program, biorąc pod uwagę zarówno ich metodologiczny charakter, jak i ówczesny kontekst ideologiczny polskiej pedagogiki. Widoczny tu minimalizm wprost wynikał z założeń szkoły - nie ma tu zatem próby konstruowania systemów pedagogicznych, wartościowania ani formułowania twierdzeń normatywno-etycznych. Analiza filozoficzna w pedagogice ma jedynie umożliwić, jak wcześniej zostało wspomniane, w sposób szeroki i pogłębiony charakterystykę teoretycznego aspektu przedmiotu pedagogiki. Nie oznacza to jednocześnie, że Sośnicki odrzucał potrzebę budowania praktycznej wiedzy pedagogicznej, zarówno w postaci wskazówek pedagogicznych, jak i norm czy systemów i koncepcji. Realizacja programu pedagogiki filozoficznej ma stanowić warunek konieczny jakichkolwiek dalszych zabiegów badawczych, mających ostatecznie na celu wygenerowanie całości wiedzy w odniesieniu do wychowania, zarówno w aspekcie teoretyczno-opisowym, jak i praktyczno-normatywnym, z tym że kompetencje pedagogiki filozoficznej kończą się na pierwszym z nich. 


\section{Podsumowanie}

Jak starałem się wyżej krótko wykazać, Kazimierz Sośnicki w pełni zasługuje na miano reprezentanta Szkoły Lwowsko-Warszawskiej w polskiej pedagogice. Wynika to nie tylko z faktu jego kształcenia pod opieką naukową twórcy szkoły czy faktycznej działalności na rzecz podniesienia kultury logicznej wśród studentów, lecz głównie ze sposobu prowadzenia badań pedagogicznych. Jego działalność naukowa była nie tylko przeniesieniem idei Szkoły Lwowsko-Warszawskiej na grunt pedagogiki, lecz także w pewnym stopniu twórczym ich rozwinięciem (świadczy o tym między innymi fakt sformułowania programu pedagogiki filozoficznej). Ostatecznie jednak jego program precyzyjnych, systematycznych, nienormatywnych analiz (w tym: rekonstrukcji) pojęć i systemów pedagogicznych w szerszym wymiarze praktycznie nie został podjęty. Częściową jej kontynuację współcześnie można odnaleźć w wybranych pracach niektórych filozofujących pedagogów, a wcześniej u S. Wołoszyna (1961, 1997), który o Sośnickim pisał między innymi:

Do wyjątków należą w naszej pedagogice postacie pedagogów tej miary, co Kazimierz Sośnicki, którego styl uprawiania pedagogiki polegał na bezustannej analizie jej podstawowych pojęć: co one znaczą i jak można i trzeba je wielorako rozumieć? (Wołoszyn, 1997, s. 11).

W myśli anglosaskiej nurt analityczny (Analytic Philosophy of Education) - inaczej niż w Polsce - był i nadal jest jednym z głównych w badaniach filozoficznych nad zagadnieniami wychowania. Wystarczy tu wspomnieć o takich nazwiskach, jak D.J. O'Connor (1957), I. Scheffler (1960), C.D. Hardie (1962), R. Peters (1973). Dostrzegając problem między innymi wielości problemów filozoficzno-etycznych w pedagogice, jej statusu naukowego, zaangażowania ideologicznego czy braku pogłębionej wewnętrznej krytyki, wydaje się, że warto podjąć takie badania na nowo. Polska myśl filozoficzna w postaci dokonań Szkoły Lwowsko-Warszawskiej i pedagogiczna w postaci Kazimierza Sośnickiego dostarczają ku temu odpowiednich narzędzi.

\section{Bibliografia}

Gajdamowicz H. (1991). Teoria wychowania i nauczania Kazimierza Sośnickiego w świetle założeń pedagogiki filozoficznej. Wydawnictwo Uniwersytetu Łódzkiego, Łódź.

Glock H.J. (2008). What is Analytic Philosopyhy?. Cambridge University Press, Cambridge. Hardie C. (1962). Truth and Fallacy in Educational Theory. Teachers College Bureau of Publications, New York. 
Moroz J. (2013). Dyskusja z relatywizmem prawdy w Szkole Lwowsko-Warszawskiej. Scholar, Warszawa.

Nalaskowski W. (1997). Pedagogika i dydaktyka w ujęciu Kazimierza Sośnickiego. Wydawnictwo A. Marszałek, Toruń.

O'Connor D. (1957). An Introduction to Philosophy of Education. Routledge, London. Peters R.S. (1973). The Philosophy of Education. Oxford University Press, Oxford.

Scheffler I. (1960). The Language of Education. Thomas, Illinois.

Sośnicki K. (1929). Zarys logiki dla klas wyższych szkół średnich ze szczególnem uwzględnieniem seminarjów nauczycielskich. Książnica - Atlas, Lwów-Warszawa.

Sośnicki K. (1946). Pedagogika ogólna: podręcznik dla użytku zakładów kształcenia nauczycieli. Librarium, Inowrocław.

Sośnicki K. (1948). Dydaktyka ogólna. Wydawnictwo Uniwersytetu Mikołaja Kopernika, Toruń.

Sośnicki K. (1964). Istota i cele wychowania. Nasza Księgarnia, Warszawa.

Sośnicki K. (1966). Jak studiować dzieło pedagogiczne. „Oświata i Wychowanie”, wyd. 3.

Sośnicki K. (1967). Rozwój pedagogiki zachodniej na przełomie XIX i XX wieku. PZWS, Warszawa.

Sośnicki K. (1971). Poradnik dydaktyczny. PZWS, Warszawa.

Sośnicki K. (1998). Jak rozumieć pedagogikę filozoficzną?, w: S. Wołoszyn (red.), Źródła do dziejów wychowania i myśli pedagogicznej, t. 3, ks. 2. Wydawnictwo Strzelec, Kielce, s. 97-103.

Woleński J. (1984). Szkoła lwowsko-warszawska. „Humanitas. Z Zagadnień Filozofii i Kultury Współczesnej”, t. IX.

Woleński J. (1985). Filozoficzna szkoła lwowsko-warszawska. PWN, Warszawa.

Woleński J. (1997). Szkoła Lwowsko-Warszawska w polemikach. Scholar, Warszawa.

Woleński J. (2005). Lwowsko-warszawska szkoła, w: Powszechna encyklopedia filozofii, t. VI. Katolicki Uniwersytet Lubelski, Lublin, http://www.ptta.pl/pef/pdf/l/lws.pdf (dostęp: 20. 01.2017).

Wołoszyn S. (1961). Analiza funktora "powinien” w pedagogicznych zdaniach normatywnych. „Kwartalnik Pedagogiczny”, nr 3.

Wołoszyn S. (1997). Kategoria "powinności” jako podstawowa aksjologiczna kategoria pedagogiki. Jak ją rozumieć?, w: T. Kukołowicz, M. Nowak (red.), Pedagogika ogólna. Problemy aksjologiczne. Redakcja Wydawnictw KUL, Lublin. 